\title{
An Investigation into the Early Stages of New Zealand's Voluntary Carbon Market
}

\author{
S. Jeff Birchall, Maya Murphy, and Markus J. Milne
}

\section{Authors:}

S. Jeff Birchall*

jeff.birchall@ualberta.ca

Department of Accounting and Information Systems, University of Canterbury, Private Bag 4800, Christchurch, 8140, New Zealand. Currently with the Department of Earth and Atmospheric Sciences, University of Alberta, Edmonton, Alberta, Canada

Maya Murphy

mayamurphy@hotmail.com

Department of Accounting and Information Systems, University of Canterbury, Private Bag 4800, Christchurch, 8140, New Zealand

Markus J. Milne

markus.milne@canterbury.ac.nz

Department of Accounting and Information Systems, University of Canterbury, Private Bag 4800, Christchurch, 8140, New Zealand

*Corresponding author.

\begin{abstract}
The voluntary carbon market (VCM) is a relatively mature field where institutions have become firmly established. This empirical paper explores findings obtained from interviewing key actors within the VCM in New Zealand, at a time when the organizational field was beginning to emerge (2010/2011). Fourteen semistructured interviews were carried out with managers and decision-makers at thirteen organizations, representing a cross-section of leaders in the field at the time. Participants were investigated regarding their cognitions as well as their operational activities and interactions with the range of actors in the field, and how these evolved over time. Case studies of the wine industry, the taxi industry, and the carbon service industry are presented. Findings identify a number of early successes, including endeavors which focused on promoting market integrity through infrastructure and knowledge sharing amongst participants, which influenced others to shift behavior around climate change mitigation in general. Setbacks are evident as well, with the primary setback characterized as market stagnation: buyers and sellers drifting away from the market. Communication challenges, low certification recognition, risk of greenwash exposure, policy uncertainty, the global financial crisis, and general disenchantment with the carbon market were listed as some of the causes.
\end{abstract}

Keywords: Organization behavior, carbon service industry, institutional frameworks, carbon management strategies, carbon offsetting

Forthcoming in Carbon Management 


\section{Introduction}

Atmospheric concentrations of greenhouse gases (GHG) are increasing as a result of the burning of fossil fuels (e.g. Hansen, Sato and Ruedy 2012). This destabilization of the Earth’s climate system has resulted in an increase in global average temperatures and will lead to more extreme weather events and sea-level rise (IPCC 2013), with potentially disastrous ecological and societal consequences. Finding a solution to climate change has taken centre stage in international policy discussions. The mitigation strategy upon which much of the international governmental policy focus currently lies is the use of carbon markets (e.g. Newell, Pizer and Raimi 2013; Lo 2016). Indeed, given the decentralized and global nature of markets (e.g. Backstrand and Lovbrand, 2006), it has the potential to compel emission reductions in an economically efficient manner. Unlike the sulphur dioxide market, however, which is held up as a model of market effectiveness to solve an environmental problem (Burtraw and Palmer 2004), GHG emissions are a global problem deeply embedded with economic success and produced by a wide variety of actors. It is thus particularly challenging to implement an effective scheme that is equitable for all countries and all sectors. As a result, carbon markets are emerging in all shapes and sizes: international, national and regional, voluntary and compliance, sector specific and multi-sector spanning.

Emerging in tandem with a focus on carbon trading are the concepts of 'carbon neutrality' and 'offsetting.' Offsetting, where released carbon emissions in one place are counter-balanced by the purchase of emission reductions or sequestration elsewhere, is an integral part of carbon markets, both voluntary and compliance based, and a body of academic work has grown around this field (e.g. Lovell and Ghaleigh 2013; Balderas Torres, MacMillan, Skutsch and Lovett 2015). 
Arising in conjunction with the concept of offsets is the controversial notion of carbon neutrality. At its best, carbon neutrality implies that emissions are measured, reduced in so far as is considered practical, and the remaining 'unavoidable' emissions are offset (WBCSD/ WRI 2004).

Both concepts have sparked academic interest and controversy (e.g. Lovell and Liverman 2010; Milne and Grubnic 2011; Birchall, Ball, Mason and Milne 2013). Critics caution the potential of carbon offsetting to perpetuate a business as usual mentality (e.g. Dhanda and Hartman 2011; Harding and Rapson 2014), where the purchase of offsets may be preferred over emissions reductions. The efficacy of offsetting itself has been challenged (e.g. Spash 2010), and concern surrounds the effectiveness of offsets to reduce GHG emissions (e.g. Ziegler and Schwirplies 2014).

A number of studies have explored behavior around willingness to pay for carbon offsetting (e.g. Schwirplies and Ziegler 2016; Segerstedt and Grote 2016), the value of certified versus noncertified carbon offset programs (e.g. Mackerron Egerton, Gaskell, Parpia and Mourato 2009), and legitimacy of carbon certification standards in general (e.g. de la Plaza Esteban, VisserenHamakers and de Jong 2014).

Nevertheless, a service industry of certifiers, auditors and consultants has emerged to provide the market with the necessary 'social infrastructure' (Voß 2007), and proactive organizations are exploring management strategies and action plans for emissions reductions (e.g. Bebbington and Barter 2011; Lee 2012; Wade, Dargusch and Griffiths 2014). 
Organizations face obvious tensions and paradoxical motives between their desires to strategically manage and reduce ecological impacts and desires to grow and succeed economically (e.g. Rankin, Windsor and Wahyuni 2011). While organizations aim to distinguish themselves from rivals, they also seek to manage reputational interdependence, where others' actions affect the perception of the entire field (Hargrave 2008). This contagion effect or reputational spill (Yu and Lester 2008) can drive keen organizations to leverage their innovative capacity and standout in an emerging field (Pinkse and Kolk 2010).

Stakeholder pressure and competitive considerations have been shown to be primary drivers shaping business strategies (e.g. Sprengel and Busch 2011; Bottcher and Muller 2013), ethical considerations and societal pressures are also factors leading organizations down this path (e.g. Hrasky 2012; Besio and Pronzini 2014). For others, participation is linked to a desire to influence policy and regulations (e.g. Haigh 2008).

As international policy responses to climate change evolve, participation in the voluntary carbon market (VCM) has become a preferred option for organizations looking to offset their carbon emissions, and a growing literature has developed around this subject (e.g. Birchall, Murphy and Milne 2015; Gray 2014; Kollmuss and Lazarus 2011). At its root, the VCM offers organizations (as well as individuals) the opportunity to reduce emissions without the restrictions of a regulatory framework. However, skepticism exists around whether voluntary carbon trading on its own (without compliance or a cap, for example) can result in absolute emission reductions (e.g. Wittneben, Okereke, Banerjee and Levy 2012). ${ }^{i}$ Further, as scholarship suggests, 
organizational support for voluntary carbon trading may simply be in an effort to stave off stricter compulsory measures by government (e.g. Birchall et al 2015).

Although certain aspects of the VCM have previously been explored, there is a gap in the academic literature with regard to which institutions emerged early on, how they were created, and what influence actors had in shaping and sustaining these new institutions (See Knox-Hayes (2010) for an exception). This research endeavors to narrow this gap. Through critical investigation at the organizational and field levels, the objective of this empirical study is to better understand the institutions that developed in the early stages of New Zealand's VCM, the cognitions and actions involved, how and by whom they were shaped, and what effect they had on participants.

Until recently, New Zealand's approach to climate change mitigation included aspiration for a carbon neutral public sector (Birchall et al. 2013) and a regulated emissions trading scheme. After a shift in government in 2008 (from Clark’s Labour-led to Key’s National-led government), however, plans for carbon neutrality were abandoned and full implementation of the emissions trading scheme were delayed (e.g. Birchall 2014). As a result of the precarious position with regard to potential carbon regulations, organizations in New Zealand were drawn to the VCM.

New Zealand offers a particularly interesting context in which to examine a VCM that has been relatively unexplored: During the early phase of the VCM, New Zealand had the $3^{\text {rd }}$ highest increase in emissions from 1990 levels of development countries (MfE 2009); New Zealand is physically small in size and geographically isolated. Along with aspirations to do its 'fair share' for climate change mitigation, these physical characteristics, provide unique well-defined and 
manageable boundaries to explore the entire range of consumption, production and services related to a carbon market.

Given the gravity of the climate change problem, it is important to explore the institutional frameworks surrounding New Zealand's VCM, as these can provide insight into participant experience and the market's ability to facilitate a low-carbon economy in New Zealand and globally.

\section{Methods}

In order to shed light on the institutions that emerged in the early phase of New Zealand's VCM, an inductive approach was adopted for this study. To gather rich, context specific narratives, qualitative semi-structured interviews were carried out with managers and decisionmakers from organizations and industries most associated with carbon neutrality in New Zealand at the time. Participants were investigated regarding their cognitions as well as their operational activities and interactions with a range of actors in the emerging field, and how these evolved over time. Interview questions were formulated to provide insight into the nature of emergent institutions in general (e.g. rules, norms, beliefs), and to identify perspectives and opinions on climate change strategies, carbon neutrality, offsetting and the interviewee's organization's involvement with the VCM in particular. A general interview outline followed four basic points:

(1) How did your organization first become involved with climate change, carbon neutrality, and buying/ selling offsets?

(2) How did you decide on the particular approach to adopt? How has your approach evolved over time?

(3) What accomplishments and setbacks have you encountered? What has worked and what would you have done differently?

(4) Where do you see the VCM and climate change strategies in general headed in the near and more distant future? 
At the time the study took place (2010-2011), 221 New Zealand organizations were identified in the field. The organizations chosen for this study represent a cross-section of offset buyers and sellers, as well as middlemen involved in early stages of the market: 2 certifiers, 2 consultants, 1 registry, 1 auditor, 3 CarboNZero certified, 1 carbon neutral noncertified, 1 looking into becoming carbon neutral, and 2 CEMARS certified (see Birchall et al (2015) for a discussion of these programs). The wine industry and the taxi industry were chosen for case studies. Both of these industries include organizations that prominently advertise themselves as carbon neutral and were among companies most associated with carbon neutrality in New Zealand. ${ }^{\text {ii }}$ The carbon services industry was also studied. This new industry rapidly evolved and expanded to fill any perceived needs associated with the carbon market, and provided an infrastructure of skills for organizational climate change actions and emissions trading.

A senior manager or relevant environmental personnel at each selected organization was interviewed. The interviews were conducted between 2010 and 2011, and included 14 interviewees at 13 organizations for a total of 20 hours of interviews (Table 1). Digital recordings of the interviews were transcribed by a professional service. Transcripts were thoroughly examined, broken down into topics, ideas, or quotes and then organized into themes for analysis. Immediately after each interview, a brief summary was put together of initial thoughts and potentially important themes and ideas brought up by the interviewee. These preliminary thoughts and themes were taken into account during a re-examination of the transcripts to ensure that no initial impressions were overlooked. ${ }^{\mathrm{iii}}$ 
Table 1 . Interviews by industry

$<$ Insert table near here $>$

\section{Findings and Discussion}

Findings are presented here in three sections, which represent the three case studies: the wine industry; the taxi industry; and, the carbon service industry. Each section details the major themes that emerged in the interviews, and provides a discussion that relates to the research objectives:

The wine industry

- Sustainability and marketplace motivations

- Measure, manage, improve

- Offsets

The taxi industry

- Conformity and radical differentiation

- Business case for environmental action

- Offsets

The carbon services industry

- Emergence of a new field

- Business opportunities

- Setting the rules, assuring market integrity

\section{The wine industry}

The wine industry in New Zealand has a longstanding tradition with sustainability. As grape growers, the industry has a direct relationship with the natural environment; wine grapes are among crops most susceptible to shifts in climate (Downey, Dokoozlian and Krstic 2006). As scholarship suggests, key wine-producing regions will experience increases in temperature and 
extreme variability in rain, ultimately stressing the industry (e.g. Fenner 2009; Jones, White, Cooper and Storchmann 2005).

Recognizing their vulnerability to climate variability, wineries were among the first business organizations in New Zealand to become involved with carbon neutrality. Three New Zealand wineries were investigated in this study: one CarboNZero certified, one aspiring to become carbon neutral and just starting to look into options on how to achieve this goal, and one that decided against carbon neutrality but is measuring and attempting to reduce its GHG emissions.

\section{Sustainability and marketplace motivations}

Sustainability is considered essential for survival of the wine industry (Galbreath 2011). This is echoed in the findings, where sustainability was found to be embedded in organizational activities. This was found to be true for the industry in general, where sustainability is institutionalized, with well-defined norms and practices regarding environmental responsibility. ${ }^{\text {iv }}$

Further, although competition and differentiation are part and parcel of the industry, there was an underlying sense that New Zealand wineries are all in it together. To this point, collaboration is encouraged, with industry seminars common practice. Networking, not only with potential customers but also with other wineries, had become integral in promoting the sharing of ideas. 
Given the industry’s inclination toward environmentally friendly practices, and with the institutional foundations already in place, attention to climate change and carbon emissions management was considered a logical next step.

In line with industry buy-in for better control on emissions, customers were found to be a further catalyst for action. As noted in the literature (e.g. Besio and Pronzini 2014), customers have a growing awareness of climate change, which often translates into changing expectations regarding businesses’ environmental actions.

New Zealand wineries aim to serve the high-end market. As a result, and in line with scholarship in this area (e.g. Cohen and Vandenbergh 2012), environmental certification was viewed by producers as a way to stay competitive in the marketplace.

However, challenges persisted. The food miles debate and buy-local advertising, for example, had put a cloud over New Zealand exports distant from their trade market. While this is not a concern unique to New Zealand, it is particularly poignant in New Zealand given it's distance from global markets (e.g. Stancu and Smith 2006). The wineries realized that they ignore that debate at their peril.

For Wine 1 (Table 1), carbon neutrality was 'a means of negating those claims for food miles' by accounting for and offsetting all emissions as far as the destination port. But for nonexporters the push for action was not as strong. In the domestic market the majority of customers' indifference was not providing enough incentive to change. For some the motivation for mitigation 
was found to be primarily financial rather than purely environmental, and thus the costs were seen to outweigh the market value of becoming carbon neutral.

For others, environmental certification was a vital part of their business strategy: 'We see it as a marketing imperative for a company with our ethos' (Table 1, Wine 1). Yet certification does come at a cost, with certifiers charging a royalty to put their brand on bottle labels. This risk was found to be compounded by doubt regarding the value of such labelling because of widespread ignorance regarding the meaning of the various certifications among consumers. ${ }^{\mathrm{v}}$

While studies suggest that consumers are interested in labeling around low-carbon products (e.g. Li, Long and Chen 2017), the seeming confusion and low logo recognition for carbon neutral certifications, was not a promising sign for organizational uptake and propagation of the certifications in New Zealand's wine industry.

Measure, manage, improve

Emissions measurement is considered the first step toward emissions reductions. This was confirmed in the interviews with all three interviewees mentioning the importance of measurement while describing their approach to emissions management.

Quantification was held to be an ongoing process in order to evaluate attempts to reduce emissions. Knowing the largest sources of emissions helps to determine and prioritize actions to be taken. 
However, there was a perceived limit to control over emissions sources. For example, packaging and refrigeration are major sources of emissions in the industry (e.g. Colman and Paster 2009).${ }^{\text {vi }}$ Both of these sources are considered outside of the winery's control: packaging is obtained from an external supplier and loss of refrigerant gases is deemed unavoidable given the current technology available. This apparent inability to affect change was found to be a barrier to organizational emissions reductions.

Nonetheless, there is potential to reduce emissions by influencing the supply chain (e.g. Blass and Corbett 2017; Plambeck 2012); both Wine 1 (Table 1) and Wine 3 (Table 1) noted that they were able to achieve significant intensity reductions by pressuring their supplier to reduce glass bottle weights. Although there are win-win benefits to reducing emissions (for example, reducing the amount of glass per bottle consequently reduces the cost of packaging), the required initial financial and/or personnel-based investments were seen as obstacles to climate change actions.

Certification and audit systems with specified goals of continual improvement add accountability and provide further motivation by enforcing a certain level of action. Wine 3 (Table 1) described how their previous experience with both effective and ineffective audit systems affected their climate change strategy and reinforced their decision to adopt certification and continual emission audits:

Having a one off energy audit didn’t work because there was no follow-up; We already knew from other audit systems we have in place based on continual improvement that once you have a certification and you have an independent audit you actually have people that are motivated to do something about it and that becomes part of the organization. 
When systems become part of the organization, actions are enforced all the way down the chain of command.

Offsets

Given the controversy surrounding offsets (e.g. Spash 2010; Milne and Grubnic 2011), transparency and legitimacy are key to organizational emissions offsetting practices. Reforestation offsets were considered the most credible and easiest for the end consumer to understand.

Co-benefits to the general ecosystem also made reforestation offsets attractive. Moreover, inline with the literature (e.g. Balderas Torres et al 2015), local based credits were generally preferred as they are seen to benefit the community and are often perceived as more legitimate. ${ }^{\text {vii }}$ Sourcing credits locally can also be mutually beneficial for the buyer and the seller: 'We knew the farmer that was selling these credits, so it was that relationship; he'd tell our story - we'd tell his story' (Table 1, Wine 1). However, other considerations such as price and availability also factored into the equation.

The three wineries examined had very different relationships with offsetting: Wine 1 had purchased offsets for several years and planed to continue along this route, Wine 2 was looking into purchasing offsets, and Wine 3 had decided against it. The perceived variance in legitimacy of the approaches affected their choice of actions. As the literature suggests, offset policies are in need of reform in order to ensure that sequestration projects achieve real and additional carbon removals (e.g. Galatowitsch 2009). 
For Wine 2 (Table 1) offsetting was viewed as 'probably a useful alternative to nothing', that is to doing nothing. They were deciding between going with an established program or doing it themselves. Balancing financial/ market volatility versus legitimacy considerations was central in their decision making process.

\section{The taxi industry}

Taxi companies in New Zealand were among business organizations most linked to urban pollution, greenhouse-gas emissions, and fossil-fuel usage. The industry shake-up with the hybrid vehicle movement provides an interesting case study. Taxis have become among companies most associated with carbon neutrality in New Zealand, in part due to their highly visible street presence and advertising. Three New Zealand taxi companies were investigated. All three advertised themselves as carbon neutral; one was self-proclaimed carbon neutral while the other two were CarboNZero certified.

\section{Conformity and radical differentiation}

The taxi industry in New Zealand is a mature industry which had, until 20 years ago, been highly regulated by the Government, leaving a legacy of prescribed actions. This meant 'you don’t need to have a customer focus, that disappears because you've got a captured market' (Table 1, Taxi 3, Y1, R1). The mature and settled nature of the industry resulted in conformity and uniformity. 
Because the taxi industry is considered inherently polluting (Mourato, Saynor and Hart 2004), shifting towards new (green) technologies can challenge business-as-usual (Calza, Parmentola and Tutore 2017). Within New Zealand's taxi industry, the combustion engine was the norm and so even when new technology became available there was hesitance to venture into unchartered territories. Taxi companies' unique organizational structure with drivers essentially operating their own business made it particularly challenging to impose new measures.

In New Zealand, the greatest barrier for established taxi companies to adopt climate change actions was 'overcoming objections from operators within the company itself' (Table 1, Taxi 2). This is apparent elsewhere in the literature, where Gao and Kitirattragarn (2008), for example, highlight operator age, experience and income as limiting factors in shifting to hybrid electric vehicles.

Driver buy-in is essential. But, the polluting nature of the industry made it seem incompatible with environmental actions. Climate change actions and hybrid vehicles were initially seen as a fad and mocked. However, industry pressures would later provide a platform for a step change within the industry and pave the way for the hybrid movement.

Green Cabs was the first carbon neutral taxi company in New Zealand. An industry outsider, Green Cabs was a rarity in the stagnant taxi industry. This entrepreneurial spirit is evident in the literature (e.g. Dargusch and Griffiths 2014), with proactive organizations pushing innovation on climate change action. Unconstrained by typical industry logics, the company sought radical differentiation rather than conformity. Not only did Green Cabs establish a hybrid- 
only fleet, the taxis were painted bright green. Some in the industry saw this as 'gimmicky', but the bold new marketing worked, as admitted by their chief competitor:

Green Cabs came out and they, to be quite honest, pretty much rocked us to the core. They were much smaller but they were getting a lot of business. That was a good marketing ploy on their behalf. (Table 1, Taxi 2)

The company also benefited from good timing, launching in late 2007 when a lot of media attention in New Zealand was being paid to climate change, in particular since Government had implemented the Carbon Neutral Public Service program to cut government departments' GHG emissions (Birchall et al 2013; Birchall 2014).

Using Green Cabs was an easy and visible way for organizations and individuals to show that they were doing something for the environment. With that said, the taxi industry's tradition of conformity led to innovations being met with resistance. Unlike the wine industry where collaboration was favoured, competitors in the taxi industry tried to discredit novel actions. Although some taxi companies had already gradually and quietly started using hybrid technology, the sudden initial success of Green Cabs legitimized and sped-up the uptake of environmentally friendly actions.

\section{Business case for environmental action}

The rise of Green Cabs forced other taxi companies to take notice. Mobilization was necessary to maintain a competitive edge in the changing marketplace. For Taxi 2 (Table 1), becoming carbon neutral certified was "marketing, a business concept” to counter the arrival of the new green company. Scholars echo this logic, indicating that climate action is increasingly considered a competitive advantage (e.g. Sullivan and Gouldson 2013; Spremgel and Buscg 2011). 
In the taxi industry, the business case for moving beyond the comfort of conformity had been established, and whereas previously environmental actions had been mocked within the industry, they became legitimized and accepted as a means of competitive business practice.

Investing in a hybrid vehicle was rationalized on an economic basis with the initial higher price counterbalanced by fuel savings. Taxi 1 (Table 1) explained to potential drivers who worried about affording the hybrid cars needed to join his company that 'the petrol savings alone would pay for the vehicle over the life of the car.' This rationale was strengthened year on year as the price of the technology dropped and the price of petrol increased. The number of kilometres one puts on a vehicle is another key contributing factor in determining cost efficiency. In this respect, Graham-Rowe, Gardner, Abraham, Skippon, Dittmar, Hutchins and Stannard (2012) highlight that low mileage usage may prove more costly, given the initial purchase cost and ongoing maintenance.

Customers' predominantly positive reaction to hybrids has softened the widely held notion that only larger vehicles work successfully as taxis. Attracting customers and gaining a marketing advantage further strengthened the business case. Positive word-of-mouth from early adopters influenced other drivers to come on board. As hybrids gained more visibility in the industry, they became not just a viable option but a preferred one. Further, since companies already had vehicle replacement policies which specified that vehicles need to be replaced every six to 10 years, modification of this policy to restrict the types of new vehicles allowed in the fleet could force a shift away from the standard petrol cars and greatly reduce GHG emissions. 
Offsets

Carbon neutrality and environmental claims involve deviating from accepted industry norms and thus are frequently subject to skepticism and scrutiny. All three interviewees mentioned either dealing directly with investigations by the Commerce Commission (Taxi 1 and Taxi 2) or concerns surrounding greenwash (Taxi 3). For Taxi 2 and Taxi 3, certification was seen as way to validate environmental actions. The guidelines, prescribed actions and third party verification involved in the certification process was found to alleviate credibility concerns.

Taxi 1, on the other hand, believed that those processes were unnecessary, 'an extra series of steps just so that you fit in'. Taxi 1 (Table 1) chose to forego certification and simply planted trees.

Further, apprehensiveness often arises from the emissions’ offsetting portion of carbon neutrality. A main concern among the interviewees was that offsetting is used as a façade to avoid taking personal responsibility. This is echoed in the literature as well, where Mackerron et al. (2009) liken offsets to religious indulgences - a means to compensate for ones sins. Moreover, offsets also have the inherent risk of perpetuating a business-as-usual mentality, where net emissions fail to decrease (e.g. Harding and Rapson 2014).

As for credits, Taxi 2 and Taxi 3 indicated a preference for local credits (though cost and availability also factored into their decision), while Taxi 1 invested in projects in developing countries. Taxi 1 held that these projects would more cost effectively help the environment. All three companies supported their position and interests by trying to discredit the other side. 


\section{The carbon services industry}

New Zealand's carbon services industry emerged in conjunction with the carbon market. Unlike in other carbon markets (in China for instance), where key institutional expertise was lacking from the outset (e.g. Lo and Yu 2015), New Zealand's carbon services industry rapidly evolved and expanded to fill any perceived needs associated with the market. Consultants, certifiers and auditors provided an infrastructure of skills for organizational climate change actions and emissions trading. In the voluntary market in particular, where rules are undefined, these actors occupied a critical position by advising their clients and thus influencing emerging norms and practices (Birchall et al 2015). Two carbon neutral certifiers, two consultants, one auditor, and one offset registry were included in this study.

\section{Emergence of a new field}

Organizations are increasingly exploring ways to manage their ecological impact while maintaining economic success (e.g. Rankin et al 2011). The creation of a carbon market commoditized environmental protection actions by attributing a tangible commercial value to GHG emissions. Institutional factors for the carbon services industry that developed to support the market resulted from a blending of existing logics put to a new problem: climate change. This was evidenced by how the service providers described becoming involved in this nascent field. For example, Consultant 1 owned a wilderness park and had a longstanding interest in nature restoration. The carbon market opened up new financial avenues for reforestation and thus Consultant 1 became involved in providing reforestation offsets and related consulting services. 
Consultant 2 also aligned their environmental and forestry background to the problem of climate change, working as a project developer, educator, and policy specialist. Consultant 2 (Table 1) developed forest conservation projects in New Zealand and the Pacific Islands after finding a need and an opportunity to use the market as an incentivizing tool. Likewise, Certifier 1 started from an environmental perspective and then turned it into a commercial opportunity. Certifier 2 came at climate change from a highly successful entrepreneurial background, and was drawn to start a business in carbon trading because environmental actions associated with the carbon market seemed to be the next high growth industry.

In contrast, the founders of Registry 1 had no previous experience in the environmental industry or in markets, but they did have extensive business and executive experience. The registry was started for 'purely business and commercial reasons' (Table 1, Registry 1). They endeavored to fill a structural hole found in the emerging carbon market (XXXX 2016); infrastructure was needed to assure market integrity and give participants confidence in the marketplace. Auditor 1 similarly assured the integrity of climate change actions and claims. As a major accounting firm, they provided professional services to businesses. The firm's services evolved to support the changing needs of their clients, in this case creating a sustainability and climate change practice.

\section{Business opportunities}

As evidenced in business and organization literature in general (e.g. Knox-Hayes 2010), business logics were a central pillar for organizations to enter New Zealand's carbon services industry. The business case was discussed by interviewees not only in relation to their own activities, but also in relation to gaining buy-in from a spectrum of potential actors in the field. 
Business logics were used to promote services to clients. Similar to the taxi industry, where the business case rather than the fear of climate change was presented to gain driver buy-in, carbon service providers focused on the opportunities and liabilities associated with carbon to gain clients.

Changing behavior is largely dependent on the associated financial implications (e.g. Okereke and Russel 2010). ${ }^{\text {viii }}$ Pricing carbon or energy savings into investment decisions (for example whether or not to adopt clean technology) can drive change by altering the dynamics of marginal cost curves. However, policy changes and the resulting uncertainty in the market complicate these decisions. The volatility of the market and subsequent crash of the carbon price had the opposite of the desired market effect: actions were disincentivized.

The business case for taking climate change actions goes beyond strictly immediate financial implications. There was also a belief among the interviewees that organizations demonstrating environmental responsibility are more successful than their competitors.

Setting the rules, assuring market integrity

Ensuring and assuring integrity of the market was mentioned by interviewees as a way to limit liabilities and mitigate risks. As Auditor 1 noted, the challenge with voluntary markets is that ‘the road map isn’t as prescriptive’ (Auditor 1). Many of the interviewees talked about 'carbon cowboys' or 'sharks' taking advantage of the system. Indeed, this is evident in organization/ business scholarship in general, where it has been shown that the lack of defined rules opens voluntary markets to abuse (e.g. Dhanda and Hartman 2011). Establishing rules thus helps to give confidence in the market. 
However, what constitutes quality and what rules are needed to ensure integrity of the carbon market is hotly debated. The interviewees highlighted a number of critical concepts (e.g. additionality; permanence; double counting of offsets; standards and rules) that were commonly debated. As with the literature in this area (Mackerron et al 2009), many of the interviewees had strongly held, often opposing, views on these issues.

Additionality, for example, is widely accepted as a prerequisite for creating carbon credits and is included as a requirement in all major standards. All of the interviewees mentioned the concept and only one questioned its validity. Consultant 1 argued that it penalized people for their initiative; early movers should be able to get carbon finance to maintain their activities.

Two interviewees, Consultant 1 and Energy 1, were directly involved in creating and selling offsets. And although their projects passed additionality tests and their offsets were purchased by reputable organizations, both acknowledged that their activities likely would have occurred without financing from the carbon market. For example, the forest regeneration project by Consultant 1 had slowly begun prior to carbon financing and likely would have continued, albeit at a slower pace. The wind farm projects by Energy 1 (Table 1) were self-admittedly 'on the cusp’ of the eligibility criteria to gain revenue from carbon credits; similar projects by the company had since gone ahead without the extra revenue stream. Thus, even if additionality is viewed as a requirement, the criteria may not be stringent enough to weed out projects that would have occurred anyway. 
Permanence was another contentious issue, particularly in the forestry sector. This is clear in the scholarship as well, Chia, Fobissie and Kanninen (2016) for instance, note the importance of considering ecosystem health, potential of future logging and forest fires. Some projects were found to have complex insurance strategies and buffers to manage these risks and assure integrity of the protected carbon stocks. Consultant 2 and Certifier 1 both described using buffer zones where sequestration activities were not sold as offsets but instead were used as insurance to cover liabilities in the event of damage to the offsets carbon stocks. Consultant 1 (Table 1), on the other hand, believed that despite the best of intentions, no long-term assurances could be made.

Auditor 1, Certifier 1, and Registry 1 expressed more confidence in offsets based on renewable energy projects than forestry projects due to the issues surrounding non-permanence risks. These three organizations were heavily involved in assuring the integrity of the market and had a direct stake in managing associated reputational risks. Auditor 1 (Table 1) noted that they wouldn’t want to be 'tainted' with bad offsets, while Registry 1 (Table 1) understood that to maintain integrity ‘you’ve got to be squeaky clean’. These organizations were thus very cautious about what offsets they would accept.

As for the issue of double counting, can there even be a legitimate voluntary market in a country bound by Kyoto compliance? Or, are voluntary reductions already counted in the country's national inventory and thus any claims or credits in a voluntary market would amount to double counting? Interviewees had varied views on how this concern should be addressed. Laws in New Zealand effectively block the creation of voluntary carbon credits after 2008 when Kyoto came 
into effect. However, Consultant 1 took the stand that the carbon rights on his property were his to do with as he pleased.

The issue of double counting is not only a concern for offset sellers, but also for offset buyers and organizations making carbon neutral claims. Auditor 1 (Table 1) questioned the credibility of organizational offsetting within an expanding regulatory market. Certifier 1 whose business was centred on a voluntary program disagreed and reasoned that voluntary action, even if there is double counting, is better than no action.

One of the key ways in which the VCM differs from the compliance market relates to the legitimacy of the carbon offset or emission reduction. While the latter gains legitimacy through regulation and legislation, the former relies largely on standards. The carbon services industry played a critical role in crafting standards and programs, and thus shaping the rules and norms New Zealand's emerging VCM (Birchall et al 2015). For example, Registry 1 (Table 1) indicated that they listed credits for nine internationally-recognized voluntary standards and were actively involved in the development of the Voluntary Carbon Standard (VCS). ${ }^{\text {ix }}$ Although there was widespread use of standards, the interpretation of the rules was largely inconsistent. Therefore, standards were frequently used by service providers in combination with in-house guidelines. Programs are often more prescriptive than standards. Service providers, such as certifiers, would set rules that their clients must adhere to in a consistent way, removing any room for (mis)interpretation. 
Over time, these rules became stricter and more consistent. For example, although Certifier 1 had always required their clients to have an emissions reduction plan, they added rules in 2009 requiring achievement of reductions in order to stay in the program. Their clients reacted positively to this change. However, they also cautioned about adding too many rules.

There is a fine balance between stringency required to ensure integrity and practicality. Certifier 2 used the same standards as other certifiers but viewed their program as an option that was 'cheaper and less onerous to deal with, more commercially focused, rather than heavy handed' (Table 1, Certifier 2). Yet, Certifier 1, with a more complex bureaucratic process, held the dominant position in the marketplace. Organizations were likely responding to the legitimacy associated with Certifier 1.

\section{Conclusions}

When this study began in 2010, the New Zealand VCM was an emerging organizational field. It is thus not surprising that organizations participating in the early market, whether as offset buyers or sellers, or middlemen providing structure to the market, had a range of experiences. Importantly, the findings identify a number of early successes, including endeavors which focused on promoting market integrity through infrastructure (e.g. a registry, certification programs), as exemplified by Registry 1 and Certifier 1; and, knowledge sharing amongst participants, which influenced others to shift behavior around climate change mitigation in general.

Nevertheless, disenchantment with the emerging carbon market itself were evident. Organizations also drifted away from buying carbon credits. Registry 1 laid some of the blame on 
the media. Certifier 2 further explained that scrutiny of climate change actions discouraged organizations from getting involved with the carbon market; the risks outweighed the benefits.

Another major impediment identified by interviewees was the global financial crisis. Uncertainty and divisive politics surrounding future Government policies further aggravated organizational wariness to take action. Political support at the level of New Zealand society as a whole had recently melted.

The importance of this research is linked to the urgency of the climate change problem. While this study provides insight into the early stages of the VCM, the state of the market in New Zealand has indeed changed since the study occurred. For example, mitigative approaches, such as hybrid vehicles, have become more attractive (e.g. Nilsson and Nykvist 2016) and the trend in carbon offsets cost has decreased markedly (e.g. Mundaca and Richter 2013; Richter and Chambers 2014). ${ }^{\mathrm{x}}$

In parallel, the global trend in carbon offsets traded has varied since New Zealand's voluntary program began, with a global peak around 2010, following with a decline. While it is difficult to pinpoint a direct cause for the decline, insight may be gained by exploring the nature of supply and demand, as well as the relationship between the voluntary and compliance carbon markets (e.g. Forest Trends’ Ecosystem Marketplace 2017). In New Zealand, while obligations associated the ETS remain transitional (and unclear), decision-makers may further appreciate the VCM as another tool in the box to help abate New Zealand's increasing GHG emissions. Indeed, 
thanks to global support of the 2015 Paris Agreement, the voluntary market may begin to experience a boost in general. ${ }^{\mathrm{xi}}$

Through critical investigation at the organizational and field levels, this paper explores the successes and challenges participants experienced in the early stage of New Zealand's VCM. While further research is necessary to assess how the institutional field has evolved through time, ${ }^{\text {xii }}$ insights gained by this study can shed light on the nuances of market participation in general, as well as help policy-makers and stakeholders better understand the market's (in)ability to facilitate a low-carbon economy in New Zealand. Moreover, though it is not assumed that findings can be generalized beyond the New Zealand context, this study nonetheless offers a comparative reference point for organizations in other countries seeking to engage or shape a VCM.

\section{Ethical approval}

All procedures performed in studies involving human participants were in accordance with the ethical standards of University’s of Canterbury Human Ethics Committee and with the 1964 Helsinki declaration and its later amendments or comparable ethical standards.

\section{Acknowledgements}

This work was supported by the Royal Society of New Zealand's Marsden Fund, under Grant \# 08UOC-025.

\section{Disclosure Statement}

No financial interest or benefit has arisen from the direct applications of this research. 


\section{Notes}

\footnotetext{
${ }^{i}$ With the exception of the Chicago Climate Exchange, VCMs tend to lack emissions reduction targets, government imposed or otherwise.

ii The prominence of the wine and taxi industries in New Zealand's VCM was established through a survey question, as part of the initial phase of this research program, that asked respondents to list organizations that they most associate with carbon neutrality. The total achieved survey response rate was 47\% (137 respondents) and 32\% (105 respondents) in 2010 and 2011, respectively (see Birchall et al (2016)).

iii See Birchall (2016) for a more detailed discussion about the study’s approach.

iv Sustainable Winegrowing New Zealand (SWNZ), created in the mid-90s to provide guidance on sustainable management of vineyards and wineries, is now adhered to almost universally.

${ }^{v}$ See Kollmuss, Lee and Lazarus (2014) for a discussion on the offset and credit process.

vi See Coley, Howard and Winter (2009) for an interesting discussion on carbon emissions associated with local food distribution methods.

vii See van der Gaast, Sikkema and Vochrer (2016) for a discussion surrounding improvements to accounting around forest carbon credits.

viii See Boiral, Henri and Talbot (2012) for an interesting discussion that runs counter this claim.

ix The Greenhouse Gas Protocol and ISO 14064 for measuring and reporting emissions, and the Gold Standard and the VCS for creating offsets were the most commonly used standards mentioned by the interviewees.

x See Shafiei, Leaver and Davidsdottir (2017) for a simulation-based discussion on incentives for low carbon emission vehicles.

${ }^{x i}$ However, as the cost of New Zealand units remain higher than international units, this may nevertheless remain a challenge New Zealand. For a discussion on New Zealand's ETS post Kyoto delinking, see Ormsby and Kerr (2016).

${ }^{\text {xii }}$ While this study focuses on the early stages of the VCM in New Zealand, a follow-up study is in development to provide a longitudinal dimension.
} 


\section{References}

Backstrand, K., and Lovbrand, E. 2006. "Planting trees to mitigate climate change: Contested discourses of ecological modernization, green governmentality and civic environmentalism." Global Environmental Politics 6 (1): 50 - 75.

Balderas Torres, A. MacMillan, D. C., Skutsch, M. and Lovett, J. C. 2015. "Yes-in-mybackyard: Spatial differences in the valuation of forest services and local co-benefits for carbon markets in México.” Ecological Economics, 109: 130-141.

Bebbington, J., and Barter, N. 2011. "Strategic response to global climate change: a UK analysis.” Chartered Institute of Management Accountants, 7(11): 1-10.

Besio, C., and Pronzini, A. 2014. "Morality, ethics, and values outside and inside organizations: An example of the discourse on climate change.” Journal of Business Ethics, 119: 287-300.

Birchall, S. J. 2014. "New Zealand's abandonment of the Carbon Neutral Public Service program.” Climate Policy, 14(4): 525-535.

Birchall, S. J., Ball, A. Mason, I., and Milne, M. 2013. "Managing carbon in times of political change: the rise and fall of the New Zealand Carbon Neutral Public Service program." Australasian Journal of Environmental Management, 20(1): 63-78.

Birchall, S. J., Murphy, M. and Milne, M. 2015. "Evolution of the Voluntary Carbon Market: An analysis of CarboNZero client disclosures." Social and Environmental Accountability Journal. DOI: 10.1080/0969160X.2015.1061444.

Birchall, S. J., Murphy, M., and Milne, M. 2016. "Mixed methods research: A comprehensive approach for study into the New Zealand voluntary carbon market." The Qualitative Report, 21(7): 1351-1365.

Blass, V., and Corbett, C. J. 2017. Same supply chain, different models: Integrating perspectives from life cycle assessment and supply chain management. Journal of Industrial Ecology, DOI: 10.1111/jiec.12550.

Boiral, O. Henri, J-F., and Talbot, D. 2012. "Modelling the Impacts of Corporate Commitment on Climate Change.” Business Strategies and the Environment, 21: 495-516.

Bottcher, F. C., and Muller, M. 2013. "Drivers, practice and outcomes of low-carbon operations: Approaches of German automotive suppliers to cutting carbon emissions." Business Strategy and the Environment, doi: 10.1002/bse.1832.

Burtraw, D., and Palmer, K. 2004. "SO2 cap-and-trade program in the United States: a "living legend" of market effectiveness," in W Harrington, RD Morgenstern \& T Sterner (eds), Choosing environmental policy: comparing instruments and outcomes in the United States and Europe, Resources for the Future, Washington DC, USA, pp. pp 41-66.

Calza, F., Parmentola, A., and Tutore, I. 2017. Types of green innovations: Ways of implementation in a non-green industry. Sustainability, doi:10.3390/su9081301. 
Chia, E. L., Fobissie, K., and Kanninen, M. 2016. "Exploring opportunities for promoting synergies between climate change adaptation and mitigation in forest carbon initiatives." Forests, 7(1): 24-40. doi:10.3390/f7010024.

Cohen, M. A., and Vandenbergh, M. P. 2012. "The potential role of carbon labeling in a green economy.” Energy Economics, 34(1): S53-S63.

Coley, D., Howard, M., and Winter, M. 2009. "Local food, food miles and carbon emissions: A comparison of farm shop and mass distribution approaches.” Food Policy, 34(2): 150-155.

Colman, T., and Paster, P. 2009. Red, white, and 'green': The cost of greenhouse gas emissions in the global wine trade. Journal of Wine Research, 20: 15-26.

de la Plaza Esteban, C., Visseren-Hamakers, I. J., and de Jong, W. 2014. "The legitimacy of certification standards in climate change governance.” Sustainable Development, 22: 420-432.

Dhanda, K. K., and Hartman, L. P. 2011. "The ethics of carbon neutrality: A critical examination of voluntary carbon offset providers.” Journal of Business Ethics, 100: 99-149. DOI: $10.1007 /$ s10551-011-0766-4.

Downey, M. O., Dokoozlian, N. K., and Krstic, M. P. 2006. Cultural practice and environmental impacts on the flavonoid composition of grapes and wine: A review of recent literature. American Journal of Ecology and Viticulture, 46: 219-226.

Galatowitsch, S. M. 2009. "Carbon offsets as ecological restoration.” Restoration Ecology, 17(5): 563-570.

Galbreath, J. 2011. "To what extent is business responding to climate change? Evidence from a global wine producer.” Journal of Business Ethics, 104: 421-432.

Gao, H. O., and Kitirattragarn, V. 2008. “Taxi owners' buying preferences of hybrid-electric vehicles and their implications for emissions in New York City." Transportation Research Part A, 42, 1064-1073.

Graham-Rowe, E., Gardner, B., Abraham, C., Skippon, S., Dittmar, H., Hutchins, R., and Stannard, J. 2012. "Mainstream consumers driving plug-in battery-electric and plug-in hybrid electric cars: A qualitative analysis of responses and evaluations.” Transportation Research Part A, 46(1): 140-153.

Gray, M. 2014. "Carbon markets from 2005 to 2010: Minor malfunction or fundamental failure? Recommendations for institutional and agenda reform.” Carbon Management, 2(2): 135-144.

Haigh, N. 2008. “A view backstage of climate change environmental markets.” Australasian Journal of Environmental Management, 15(2): 76-83, DOI: 10.1080/14486563.2008.9725187

Hansen, J., Sato, M., and Ruedy, R. 2012. "Perception of climate change.” Proceedings of the National Academy of Sciences, 109(37): 2415-2423.

Harding, M., and Rapson, D. 2014. "Do voluntary offsets induce energy rebound? A conservationist's dilemma." In review: Journal of the Association of Environmental and Resource Economists. 
Hargrave, T. J. 2008. "The voluntary environmentalists: Green clubs, ISO 14001, and voluntary environmental regulation.” Corporate Reputation Review, 11: 109-11.

Hrasky, S. 2012. “Carbon footprints and legitimation strategies: symbolism or action?” Accounting, Auditing \& Accountability Journal, 25(1): 174-198.

IPCC (International Panel on Climate Change). 2013. Summary for policymakers. In: climate change 2013: the physical science basis. Contribution of Working Group I to the Fifth Assessment Report of the Intergovernmental Panel on Climate Change, Stocker, T. F., Qin, D., Plattner, G-K., Tignor, M., Allen, S. K., Boschung, J., Nauels, A., Xia, Y., Bex, V. and Midgley, P. M. (eds). Cambridge University Press, Cambridge: United Kingdom and New York, NY, USA.

Kollmuss, A., and Lazarus, M. 2011. "Buying allowances as an alternative to offsets for the voluntary market: A preliminary review of issues and options.” Greenhouse Gas Measurement and Management, 1(2): 119-131.

Kollmuss, A., Lee, C., and Lazarus, M. 2014. "How offset programs assess and approve projects and credits.” Carbon Management, 1: 119-134.

Knox-Hayes, J. 2010. "Creating the carbon market institution: Analysis of the organizations and relationships that build the market." Competition and Change, 14(3-4): 176-202.

Lee, S-Y. 2012. "Corporate carbon strategies in responding to climate change." Business Strategy and the Environment, 21, 33-48.

Li, Q., Long, R., and Chen, H. 2017. Empirical study of the willingness of consumers to purchase low-carbon products by considering carbon labels: A case study. Journal of Cleaner Production, 161: 1237-1250.

Lo, A. T. 2016. Challenges to the development of carbon markets in China. Climate Policy, 16(1): 109-124.

Lo, A. Y., and Yu, X. 2015. Climate for business: Opportunities for financial institutions and sustainable development in the Chinese carbon market. Sustainable Development, 23:369-380.

Lovell, H., and Ghaleigh, N. S. 2013. "Climate change and the professions: the unexpected places and spaces of carbon markets." Transactions of the Institute of British Geographers, 38: 512-516.

Lovell, H., and Livermanm, D. 2010. “Understanding carbon offset technology.” New Political Economy, 15(2): 255-273.

MacKerron, G., Egerton, C., Gaskell, C., Parpia, A., and Mourato, S. 2009. "Willingness to pay for carbon offset certification and co-benefits among (high-)flying young adults in the UK.” Energy Policy, 37(4): 1372-1381.

Milne, M., and Grubnic, S. 2011. "Climate change accounting research: keeping it interesting and different.” Accounting, Auditing \& Accountability Journal, 24: 948-977.

MfE (Ministry for the Environment). 2009. “New Zealand's 2020 Emissions Target.” New Zealand Ministry for the Environment, July 2009. 
Mourato, S., Saynor, B., and Hart, D. 2004. “Greening London's black cabs: a study of driver's preferences for fuel cell taxis.” Energy Policy, 32(5): 685-695.

Mundaca, L., \& Richter, J. L. 2013. “Challenges for New Zealand’s carbon market.” Nature Climate Change, 3: 1006-1008.

Newell, R. G. Pizer, W. A., and Raimi, D. 2013. "Carbon markets 15 years after Kyoto: lessons learned, new challenges.” Journal of Economic Perspectives, 27(1): 123-146.

Nilsson, M., and Nykvist, B. 2016. "Governing the electric vehicle transition: Near term interventions to support a green energy economy.” Applied Energy, 179: 1360-1371.

Okereke, C., and Russel, D. 2010. "Regulatory pressure and competitive dynamics: Carbon management strategies of UK energy-intensive companies.” California Management Review, 52: $100-124$.

Ormsby, J. and Kerr, S. 2016. "The New Zealand Emissions Trading Scheme de-link from Kyoto: Impacts on banking and prices.” Motu Working Paper 16-13, Motu Economic and Public Policy Research.

Pinkse, J., and Kolk, A. 2010. "Challenges and trade-offs in corporate innovation for climate change.” Business Strategy and the Environment, 19(4): 261-272.

Plambeck, E. L. 2012. Reducing greenhouse gas emissions through operations and supply chain management. Energy Economics, 34: S64-S74.

Rankin, M. Windsor, C., and Wahyuni, D. 2011. "An investigation of voluntary corporate greenhouse gas emissions reporting in a market governance system: Australian evidence." Accounting, Auditing \& Accountability Journal, 24(8): 1037-1070.

Richter, J. L., and Chambers, L. 2014. "Reflections and outlook for the New Zealand ETS: Must uncertain times mean uncertain measures?” Policy Quarterly, 10(3): 57-66.

Schwirplies, C., and Ziegler, A. 2016. "Offset carbon emissions or pay a price premium for avoiding them? A cross-country analysis of motives for climate protection activities." Applied Economics, 48(9): 746-758.

Segerstedt, A., and Grote, U. 2016. "Increasing adoption of voluntary carbon offsets among tourists.” Journal of Sustainable Tourism, 24(11): 1541-1554.

Shafiei, E. Leaver, J., and Davidsdottir, B. 2017. "Cost-effectiveness analysis of inducing green vehicles to achieve deep reductions in greenhouse gas emissions in New Zealand.” Journal of Cleaner Production, 105: 339-351.

Spash, C. L. 2010. “The brave new world of carbon trading.” New Political Economy, 15(2): 169-195.

Sprengel, D. C., and Busch, T. 2011. "Stakeholder engagement and environmental strategy the case of climate change.” Business Strategy and the Environment, 20(6): 351-364.

Stancu, C., and Smith, A. 2006. "Food miles: The international debate and implications for New Zealand exporters.” Landcare Research Business \& Sustainability Series. viewed 3 
January

2017,

$<$ http://www.landcareresearch.co.nz/research/sustainablesoc/business/trade/documents/food

$\underline{\text { miles.pdf }>\text {. }}$

Sullivan, R., and Gouldson, A. 2013. "Ten years of corporate action on climate change: what do we have to show for it?” Energy Policy, (60): 733-740.

van der Gaast, W., Sikkema, R., and Vohrer, M. 2016, “The contribution of forest carbon credit projects to addressing the climate change challenge." Climate Policy. DOI: 10.1080/14693062.2016.1242056.

Voß, J-P. 2007. "Innovation processes in governance: The development of emissions trading as a new policy instrument.” Science and Public Policy, 34(5): 329-343.

Wade, B., Dargusch, P., and Griffiths, A. 2014. "Defining best practice carbon management in an Australian context.” Australian Journal of Environmental Management, 21(1): 52-64.

WBCSD/WRI (World Business Council for Sustainable Development/ World Resources Institute). (2004). The greenhouse gas protocol: a corporate accounting and reporting standard; revised edition. World Business Council for Sustainable Development, Washington DC, United States; World Resources Institute, Geneva, Switzerland.

Wittneben, B. B. F., Okereke, C. Banerjee, S. B., and Levy, D. L. 2012. “Climate change and the emergence of new organizational landscapes.” Organization Studies, 33(11): 1431-1450.

Yu, T. Y., and Lester, R. H. 2008. "Moving beyond firm boundaries: A social network perspective on reputation spillover.” Corporate Reputation Review, 8(3): 187-97.

Ziegler, A., and Schwirplies, C. 2014. "The determinants of voluntary carbon offsetting: A micro-econometric analysis of individuals from Germany and the United States.” Annual Conference 2014 (Hamburg): Evidence-based Economic Policy, viewed 20 January 2017, <http://EconPapers.repec.org/RePEc:zbw:vfsc14:100422>. 